\title{
DESKRIPSI BIONOMIK NYAMUK Anopheles Sp DI WILAYAH KECAMATAN PARIGI KABUPATEN PANGANDARAN PROVINSI JAWA BARAT TAHUN 2016
}

\author{
Ulfah Kusuma $^{1)}$, Arif Widyanto ${ }^{2)}$ \\ Jurusan Kesehatan Lingkungan, Politeknik Kesehatan Kemenkes Semarang, \\ Jl. Raya Baturaden KM 12 Purwokerto, Indonesia
}

\begin{abstract}
Abstrak
Kondisi Desa Cibenda yang berada di dataran rendah dan berbatasan langsung dengan pantai yang menjadi muara sungai dan perairan Samudera Indonesia memungkinkan nyamuk Anopheles Spp untuk berkembangbiak, karakteristik umum habitat yang ditemukan adalah berupa rawa-rawa, kolam bekas tambak udang, lahan pertanian atau persawahan yang mendominasi juga habitat ideal bagi beberapa nyamuk Anopheles lain. Dengan metode observasional menggambarkan atau mengamati bionomik nyamuk Anopheles Spp di wilayah Kecamatan Parigi. Data yang digunakan dalam penelitian ini adalah data sekunder dan pengamatan nyamuk yang dilakukan mulai pukul 18.00-24.00 WIB dengan metode penangkapan nyamuk hinggap HLC (Human landing Collection) di dalam dan di luar rumah oleh 6 orang kolektor. Penangkapan dilakukan selama 40 menit, dilanjutkan dengan penangkapan nyamuk yang istirahat di dinding dalam rumah dan di sekitar kandang ternak (kerbau atau sapi) selama 10 menit. Hasil penelitian mengenai deskripsi bionomik nyamuk Anopheles Spp di wilayah Kecamatan Parigi yaitu di temukan 3 spesies nyamuk diantaranya An.vagus, An.barbirostris dan An.subpictus. Menurut penelitian dapat disimpulkan bahwa karakteristik lingkungan Desa Cibenda Kecamatan Parigi merupakan habitat yang ideal bagi perkembangbiakan Anopheles Spp dan fauna yang ditemukan diantaranya An.vagus 42 ekor (85,7\%), An.barbirostris 6 ekor (12,3\%) dan An.subpictus 1 ekor (2\%).
\end{abstract}

Kata Kunci : Nyamuk Anopheles Spp, Malaria

\begin{abstract}
[Bionomics Description of Anopheles Spp in Parigi, Pangandaran District, West java 2016].The condition of Cibenda village, located in the lowland and adjacent to coast which become an estuary and the waters of the Hindia Ocean, allows the Anopheles spp to breed. The general characteristics of habitat found are swamps, ponds used to be a shrimp farming, farmland or paddy field that dominate also an ideal habitat for the Anopheles mosquitoes. The method used is observational by describing and observing the bionomics of Anopheles spp mosquitoes in Parigi district. The data used in this study are secondary data and mosquitoes observation which starts from 18.00-24.00 local time by using a mosquito catching method HLC (Human landing Collection) inside and outside a house, done by 6 collectors. The result of study on the bionomics of Anopheles spp in Parigi district is the discovery of three species of mosquitoes; An.vagus, An.barbirostris and An.subpictus. Conclusion of the study is the environmental characteristics of Cibenda village of Parigi district is an ideal habitat for the breeding of Anopheles spp and the fauna found there namely 42 An.vagus (85.7\%), 6 An.barbirostris (12.3\%) and an An. subpictus (2\%).
\end{abstract}

Keywords : Anopheles Spp, Malaria

\section{PENDAHULUAN}

Menurut teori H.L.Blum, ada empat faktor yang mempengaruhi derajat kesehatan masyarakat yaitu faktor lingkungan, faktor perilaku, faktor pelayanan kesehatan, dan faktor genetik. Diantara faktor tersebut, faktor lingkungan sangat mempengaruhi derajat kesehatan masyarakat (Slamet Ryadi dan Wijayanti, 2011, h. 22).

Faktor lingkungan suhu udara geografis (ketinggian dari permukaan laut, musim) bisa berpengaruh pada kemampuan hidup parasit dalam nyamuk vektor. Plasmodium tidak bisa hidup dan

1) Email : ulfahkusumawardhani@yahoo.com

2) Email : arifwidyanto74@yahoo.com berkembang pada suhu $<16^{\circ} \mathrm{C}$. Kelembaban udara $60-80 \%$ optimal untuk hidup nyamuk dengan umur panjang. Jika nyamuk sebagai vektor semakin padat (misalnya hitungan jumlah nyamuk vektor rata-rata yang menggigit orang per jam), semakin antropofilik (lebih suka menggigit dan mengisap darah manusia) semakin panjang umurnya (>2 minggu), dan semakin rentan terhadap infeksi dengan parasit malaria setempat, maka semakin besar potensinya terjadi KLB malaria, mungkin pada musim tertentu. Faktorfaktor diatas merupakan suatu kesatuan epidemiologis yang perlu dicermati dan diteliti 
sehingga dapat digunakan sebagai acuan dalam menurunkan angka kesakitan dan kematian akibat malaria (jurnal penyakit bersumber binatang, 2013).

Bionomik nyamuk merupakan gambaran nyamuk yang meliputi perilaku nyamuk dan kondisi lingkungan. Salah satu perilaku nyamuk adalah kebiasaan nyamuk keluar untuk mencari mangsa. Pemahaman terhadap kebiasaan nyamuk untuk mencari darah, akan memudahkan kita pada waktu potensi bahaya akan terjadi, karena setiap spesies nyamuk Anopheles Spp mempunyai kemampuan infektif yang berbeda (Aris Santjaka,2013)

Dilandasi dari salah satu permasalahan tersebut maka dilakukan pengamatan secara observasi untuk mengetahui bionomik vektor nyamuk Anopheles spp yang ada di daerah endemik dan untuk mengetahui penyebaran dan kelimpahan suatu spesies dari nyamuk tersebut. Pangandaran merupakan kabupaten termuda di Provinsi Jawa Barat, sehingga diperlukan data atau riset mengenai berbagai macam penyakit yang menyerang kawasan Pangandaran. Kondisi Desa Cibenda yang berada di dataran rendah dan berbatasan dengan pantai yang menjadi muara sungai dan perairan Samudera Indonesia memungkinkan nyamuk Anopheles Spp untuk berkembang-biak. Perairan payau merupakan kondisi yang sesuai bagi perkembangan beberapa spesies nyamuk dari genus Anopheles yang mampu berperan sebagai vektor malaria.

Karakteristik umum habitat yang ditemukan adalah berupa rawa-rawa, kolam bekas tambak udang, lahan pertanian atau persawahan yang mendominasi juga habitat ideal bagi beberapa nyamuk Anopheles lain.

\section{BAHAN DAN METODE}

Penelitian ini dilakukan di Desa Cibenda Dusun Sucen Kecamatan Parigi Kabupaten Pangandaran selama setengah malam, pada tanggal 9 April 2016 dengan metode observasional, yang merupakan daerah pantai di Kabupaten Pangandaran. Survai dimulai dengan menentukan tiga rumah dan satu sebagai Catching station dengan kategori berdasarkan dengan tempat perkembang- biakkan nyamuk Anopheles Spp dengan jarak maksimal 500 meter atau rumah yang mempunyai kandang ternak. Survai dilakukan mulai pukul 18.00-24.00 WIB dengan metode penangkapan nyamuk HLC (Human Landing Collection) di dalam dan di luar rumah oleh 6 kolektor.

Penangkapan dilakukan selama 40 menit, dilanjutkan dengan penangkapan nyamuk yang istirahat di dinding dalam rumah dan di sekitar kandang ternak (kerbau atau sapi) selama 10 menit. Sisa waktu 10 menitdi setiap jamnya, digunakan untuk istirahat kolektor dan persiapan penangkapan untuk istirahat kolektor dan persiapan penangkapan pada jam selanjutnya. Nyamuk yang tertangkap dikelompokkan berdasarkan jam penangkapan (luar dan salam rumah) serta istirahat didinding dan kandang. Nyamuk yang hinggap di badan ditangkap menggunakan aspirator, kemudian nyamuk dibunuh menggunakan cloroform, dihitung jumlahnya dan diiden-tifikasi spesiesnya menggunakan microskop stereo. Identifikasi nyamuk menggunakan kunci identifikasi nyamuk Anopheles dari O’Connor dan Soepanto (1999)

\section{III.HASIL DAN PEMBAHASAN}

Penelitian ini dilakukan dengan mengukur kondisi lingkungan seperti suhu, faktor fisik dan kimia merupakan faktor abiotik yang memiliki peran penting dalam perkembangan dan penyebaran nyamuk. Berdasarkan hasil pengamatan pada malam hari penangkapan. Suhu luar dan suhu dalam ruangan pada saat penangkapan nyamuk berkisar antara $26^{\circ} \mathrm{C}-$ $29^{\circ} \mathrm{C}$ dan rata-rata suhu luar $28,7^{\circ} \mathrm{C}$, sedangkan ratarata suhu dalam $27^{\circ} \mathrm{C}$, hal tersebut terlihat dari ke enam jam yang dimulai dari jam pertama (18.00) sampai jam terakhir (24.00) yang memperlihatkan tidak ada perbedaan yang signifikan, begitu juga dengan suhu dalam ruangan dengan hasil rata-rata $27,5^{\circ} \mathrm{C}$ suhu tersebut optimum untuk perkembangan nyamuk.

Nyamuk tersebut masih bertahan hidup dalam suhu rendah, tetapi proses metabolismenya menurun atau bahkan terhenti bila suhu turun sampai dibawah suhu kritis kurang dari $16^{\circ} \mathrm{C}$ dan lebih tinggi dari $32^{\circ} \mathrm{C}$ akan mengalami peubahan proses fisiologinya (Saputro Eko, 2010)

Peningkatan suhu akan mem-pengaruhi perubahan bionomik atau perilaku menggigit dari populasi nyamuk, angka gigitan rata-rata yang meningkat (biting rate), kegiatan reproduksi nyamuk berubah yang ditandai dengan perkembang-biakan nyamuk semakin cepat, masa ke-matangan parasit dalam nyamuk akan semakin pendek. Secara teori suhu yang tinggi menyebabkan transmisi nyamuk meningkat, kemungkinan ini dikarena-kan berkurangnya masa inkubasi (Mouchet, 1998).

Kelembaban mempengaruhi kecepatan berkembangbiak, kebisaan mengggigit dan istirahat nyamuk (Harijanto, 2000). Pada kelembaban yang lebih tinggi nyamuk menjadi lebih aktif dan lebih sering menggigit, sehingga meningkatkan penularan penyakit malaria. Kelembaban yang optimum yang diperlukan untuk perkembang-biakan nyamuk di atas 60\% (Chwatt-Bruce, 1985). Pada malam penangkapan rata-rata kelembaban relatif berkisar $83 \%$

Secara tidak langsung, faktor lingkungan seperti suhu dan kelembaban udara menentukan tingkat keanekaragaman suatu spesies. Korelasi negatif dan tidak signifikan ditunjukan antara keanekaragaman dengan suhu dan kelembaban relatif pada penelitian ini. Beberapa studi telah mengemukakan hal yang sama (Pramanik, et al, 2006) maupun sebaliknya. Faktor musim dan keberadaan serta kesesuaian habitat adalah beberapa dari sekian faktor yang mempengaruhi sebaran dan kelimpahan suatu jenis di 
suatu daerah (Devi dan Jauhari, 2006: Munga, et al, 2006)

Ketinggian tempat, seperti yang di-jelaskan bahwa ketinggian tempat mem-pengaruhi terhadap kerapatan nyamuk sehingga jenis nyamuk yang didapatkan akan beragam. Ketinggian tempat di daerah Desa Cibenda 5 mdpl. Desa Cibenda dusun Sucen secara umum, malaria berkurang pada ketinggian yang bertambah, hal ini berkaitan dengan menurunnya suhu rata-rata, pada tempat perindukan Anopheles spp rata-rata ketinggian hingga $7 \mathrm{mdpl}$ dan pada tempat penangkapan nyamuk rata-rata ketinggian hingga 15 mdpl. Pada ketinggian diatas 2.000 mdpl jarang ada transmisi malaria. Ketinggian paling tinggi masih memungkinkan transmisi malaria ialah 2.500 meter di atas permukaan laut

Curah hujan Data curah hujan didapatkan di lokasi Kecamatan Parigi Desa Cibenda Sucen Parigi. Data dicatat selama 5 tahun yaitu dari tahun 2011 sampai dengan 2015. Data curah hujan dianalisis untuk menghitung indeks curah hujan (ICH) per bulan dan dihitung rata-ratanya selama 5 tahun. Pada wilayah Kecamatan Parigi, puncak curah hujan ada pada bulan Juli dan bulan November dengan maksimal ICH 376,1 pada bulan Juli, minimal ICH 0, mean ICH 143,12 serta median ICH 12,77 sedangkan ICH maksimal pada bulan November adalah 504,4, minimal ICH adalah 159,58, mean ICH 68,84, serta median ICH 407,55

Pola curah hujan pada periode tahun 2011 sampai 2015 tidak berbeda dengan pola pada periode 10 tahun sebelumnya. Unit pelayanan kesehatan untuk menanggulangi masalah malaria di wilayah Kabupaten Pangandaran sudah cukup memadai karena sudah bisa menjangkau seluruh daerah endemis malaria. Hujan yang diselingi oleh panas akan memperbesar perkembangbiakan Anopheles. Hujan dapat juga meningkatkan kelembapan relatif, sehingga memperpanjang usia nyamuk dewasa. Curah hujan minimum yang dibutuhkan oleh nyamuk untuk berkembangbiak adalah sekitar 1,5 mm per hari. Curah hujan $150 \mathrm{~mm}$ perbulan mengakibatkan perkembangan yang pesat.

Data curah hujan diperlukan karena berkaitan dengan timbulnya perindukan nyamuk dan berpengaruh terhadap habitat, fluktuasi kepadatan vektor dan kesakitan malaria serta merupakan faktor penentu penyebaran malaria (Bates, 1970). Setiap turun hujan, akan terjadi genangan air dan ini memberikan keadaaan yang menguntungkan bagi nyamuk dengan memberinya tempat perindukan. Tinggi rendahnya curah hujan akan mempengaruhi keberadaan habitat vektor malaria (Mouchet, 1998).

Curah hujan berhubungan dengan perkembangbiakan larva nyamuk. Curah hujan yang berlebihan dapat mengubah aliran kecil air menjadi aliran yang deras hingga banyak larva dan pupa serta telur-telur terbawa arus air. Sebaliknya, curah hujan yang sedikit, kolam yang tidak terawat akan mempengaruhi jenis Anopheles tertentu sehingga dapat berkembang biak sangat banyak. Nyamuk Anopheles berkembang biak dalam jumlah besar jika terjadi hujan dengan di selingi panas.

Intensitas cahaya Pengaruh sinar matahari terhadap pertumbuhan larva nyamuk berbeda-beda seperti An.barbi-rostris dapat hidup baik di tempat teduh maupun terkena sinar matahari dan tempat terbuka dengan intensitas cahaya 13.022 Lux, sedangkan tempat perindukan An.vagus dan An subpictus intensitas cahaya 10.352 Lux.

Spesies nyamuk yang tertangkap Nyamuk paling banyak tertangkap adalah An.vagus sebanyak 42 ekor (85,7\%) yaitu pada penangkapan UOL (1 ekor), pada penangkapan istirahat kandang (41 ekor) berdasarkan penelitian sebelumnya menurut Lukman hakim dkk, 2015 mengatakan paling banyak ditangkap kedua adalah An.vagus walaupun nyamuk An.vagus belum diidentifikasi sebagai vektor malaria di Pangandaran, sedangkan nyamuk yang sudah diidentifikasi sebagai vektor malaria di Pangandaran seperti An.sundaicus dan An.aconitus tidak ditemukan saat penangkapan dilaksanakan. Selanjutnya nyamuk An.barbirostris sebanyak 6 ekor $(12,3 \%)$ semuanya pada penangkapan istirahat kandang, urutan selanjutnya adalah nyamuk An.subpictus sebanyak 1 ekor (2\%)

Spesies ini terdapat di seluruh Indonesia, baik di dataran tinggi maupun di dataran rendah. Jentik An.barbirostris biasanya berkembang dalam air jernih, alirannya tidak begitu cepat, ada tumbuhtumbuhan air dan pada tempat yang agak teduh seperti sawah, bekas kolam dan parit.

Nyamuk An.barbirostris, An.vagus dan An.subpictus adalah tiga jenis Anopheles spp yang cukup melimpah di Desa Cibenda. Keberadaanya dimungkinkan karena adanya area persawahan, sungai, parit serta hutan sekunder dataran rendah. Kondisi topografi serupa denga hasil studi di Sukabumi (Munif, et al. 2007).

Desa Cibenda mempunyai wilayah persawahan dan perkebunan sehingga kedua spesies ini ditemukan di lokasi tersebut. Hal ini sejalan dengan penelitian fauna di Kabupaten Donggala, bahwa di tempat lokasi survey ditemukan adanya An.barbirostris dan An.vagus. Hasill penelitian di Halmahera sejalan dengan penelitian ini, yaitu nyamuk An.vagus ditemukan di wilayah persawahan baik larva maupun dewasa denagn kadar salinitas habitatnya adalah 0,9 (Soekirno et al., 1997). Spesies nyamuk An.vagus dan An.barbirostris juga ditemukan di habitat sawah dan rawa-rawa di Kupang, Nusa Tenggara Timur (Meomanu, 2012). Urutan selanjutnya adalah nyamuk An.subpictus sebanyak 1 ekor (2\%). Hasil penelitian ini yang menunjukan terdapat perbedaan keragaman fauna Anopheles spp, pada keadaan geografis yang berbeda. Tabel 5.4 Kepadatan Anopheles yang berhasil ditangkap di Wilayah pantai Kec.Parigi pada bulan April 2016 


\begin{tabular}{lrrrr}
\hline \multirow{2}{*}{ Spesies } & \multicolumn{4}{c}{ Kepadatan Anopheles } \\
\cline { 2 - 5 } & Indoor & Outdoor & Total & \% \\
\hline An.vagus & 0 & 42 & 42 & 85,7 \\
\hline An.barbirostris & 0 & 6 & 6 & 12,3 \\
\hline An.subpictus & 0 & 1 & 1 & 2 \\
\hline Jumlah & 0 & 49 & 49 & 100 \\
\hline \multicolumn{1}{c}{ Lebih dari } & separuh & nyamuk & Anopheles & spp \\
tertangkap melalui penangkapan metode kandang (48 \\
ekor) dengan metode Umpan Orang Luar (UOL) (1 \\
ekor). Nyamuk yang tertangkap di luar rumah 1 kali \\
lebih banyak dibandingkan yang tertangkap di dalam \\
rumah. Sedangkan pada penangkapan resting, lebih \\
dari 90\% nyamuk tertangkap di kandang ternak.
\end{tabular}

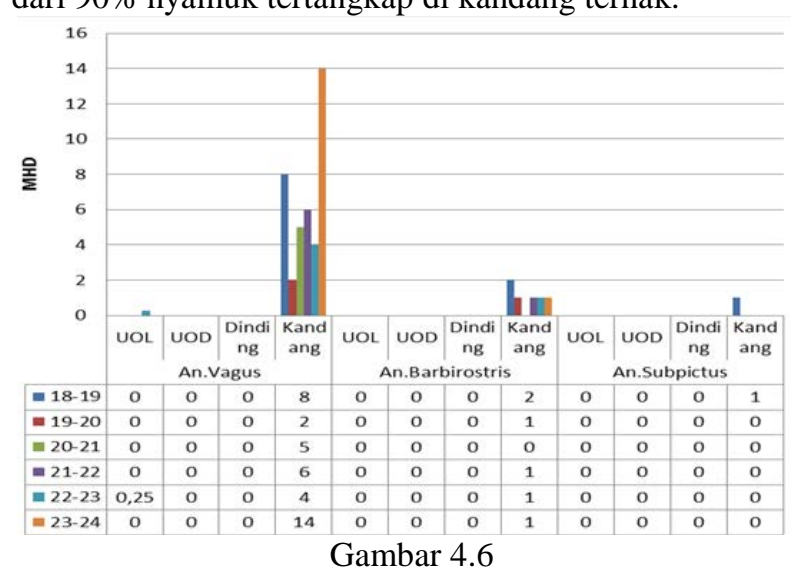

Fluktuasi kepadatan Anopheles per orang per jam (MHD) di Desa Cibenda Kec. Parigi Kab. Pangandaran Jawa Barat Tahun 2016

Nyamuk Anopheles vagus dan Anopheles barbirostris adalah dua jenis nyamuk yang selalu ditemukan pada malam penangkapan, sebaliknya Anopheles subpictus merupakan spesies nyamuk dengan frekuensi terendah selama pengamatan.

Hasil penangkapan di Desa Cibenda Dusun Sucen menunjukkan nyamuk Anopheles spp yang tertangkap dengan metode resting kandang, lebih banyak dibanding metode lain. Angka kelimpahan nisbi An.vagus adalah yang tertinggi yaitu 42 kemudian nyamuk An.barbirostris sebesar 6 dan nyamuk An.subpictus sebesar 1

Nyamuk Anopheles spp yang tertangkap di desa Cibenda dusun Sucen dominan ditemukan pada metode resting kandang,dan ada 1 spesies ditemukan pada metode umpan orang luar. An.vagus lebih dominan dibanding dengan spesies lainnya yaitu 42 ekor.

Tempat Berkembangbiak (Breeding site) nyamuk Anopheles spp. Tempat per-kembangbiakan nyamuk di Desa Cibenda Sucen Kecamatan Parigi dengan positif larva Anopheles instar I-III penular penyakit malaria (Anopheles) adalah dengan karakteristik habitat berupa kolam-kolam bekas tambak yang tidak dikelola dengan baik, parit yang tergenang, adanya penebangan hutan bakau secara liar merupakan habitat yang potensial bagi perkembangbiakan nyamuk seperti An.sundaicus dan An.subpictus hidup di air payau, An.aconitus dan An.vagus hidup di air sawah dan bekas kolam udang, dan banyak aliran sungai yang tertutup pasir (laguna) yang merupakan tempat perindukan nyamuk An.sundaicus.

Tempat perindukan jentik paling tinggi pada kolam bekas tambak udang dengan ketinggian ratarata habitat antara 7 meter di atas permukaan laut. Hasil pengukuran salinitas air berkisar antara 0,9-5,1 permil dan suhu air $36^{\circ} \mathrm{C}$ dan kedalaman atau tinggi permukaan air 50-100 cm.

Tanaman yang sering ditemukan di tempat-tempat perkembangbiakan tersebut, antara lain seperti rumput air, lumut, pohon kelapa, teratai, kangkung, serta tanaman padi dengan suhu $30^{\circ} \mathrm{C}$ Sementara itu, jenis hewan predator yang ditemukan diantaranya ikan kepala timah, kumbang, kupu-kupu, larva udang, capung. Ikan kepala timah merupakan pemakan larva nyamuk dan juga keberadaan ikan pada tempat perindukkan mempengaruhi kepadatan larva nyamuk, makin banyak ikan maka kepadatan larva semakin kecil demikian pula sebaliknya. Oleh karena itu, dengan mengetahui jenis nyamuk dan berbagai aktifitasnya di daerah staratifikasi endemisitas tinggi malaria merupakan langkah awal dalam usaha pengendalian malaria yang ditularkan oleh serangga ini.

Perilaku nyamuk dalam mencari makan sebanyak tiga jenis nyamuk Anopheles Spp ditemukan pada penangkapan nyamuk resting di sekitar kandang ternak. Nyamuk An.vagus merupakan jenis nyamuk yang suka menggigit lebih suka berada di luar rumah dan menggigit di waktu senja sampai dengan dini hari (eksofagik), puncakya pada pukul 23.00-24.00 WIB serta mempunyai jarak terbang yang jauh 1,6 km sampai dengn $2 \mathrm{~km}$. Nyamuk ini bersifat suka menggigit binatang (zoofilik) dari pada sifat suka gigit manusia (antrophofilik)

\section{IV.SIMPULAN}

Berdasarkan hasil penelitian dan pembahasan tentang Deskripsi Bionomik nyamuk Anopheles Spp di Wilayah Kecamatan Parigi Kabupaten Pangandaran Provinsi Jawa Barat Tahun 2016 dapat disimpulkan sebagai berikut

a. Karakteristik lingkungan Desa Cibenda Dusun Sucen Kecamatan Parigi Kabupaten Pangandaran merupakan habitat yang ideal bagi perkembangbiakan Anopheles Spp. Tiap habitat didominasi oleh kolam bekas tambak, parit, hutan sekunder dataran rendah dan persawahan tadah hujan yang terletak pada ketinggian 34-36 meter diatas permukaan laut dengan salinitas 0,9-5 permil. Suhu dan kelembaban udara yang dominan di Desa Cibenda yang merupakan daerah pantai berkisar antara $26^{\circ} \mathrm{C}-29^{\circ} \mathrm{C}$ dan kelembaban berkisar antara 82\%- 84\%. Pada Desa Cibenda dominan nyamuk Anopheles vagus keberadaannya dimungkinkan karena adanya area persawahan, kolam bekas tambak, parit, serta hutan sekunder daratan rendah. Faktor suhu dan kelembaban tidak secara langsung menentukan 
kelimpahan jenis.

b. Fauna nyamuk Anopheles Spp yang terdapat di Desa Cibenda Dusun Sucen Kecamatan Parigi Kabupaten Pangan-daran diantaranya spesies Anopheles vagus, Anopheles barbirostris, Anopheles subpictus. Anopheles vagus me-rupakan jenis nyamuk dengan jumlah terbanyak mencapai 85,7\% dari jumlah seluruh jenis yang ditemukan di Desa Cibenda Dusun Sucen.

c. Spesies nyamuk Anopheles vagus ditemukan menggigit mulai awal malam dan cenderung tidak ditemukan meng-gigit setelah tengah malam dan puncak menggigit terjadi antara pukul 20.0024.00 atau jam ke 6 dengan metode resting kandang sebanyak 14 ekor nyamuk. Sedangkan yang kedua pada pukul 18.00-19.00 atau jam 1 dengan metode resting kandang dan UOL (umpan orang luar) yaitu nyamuk An.vagus 8 ekor, An.barbirostris 2 ekor dan An.subpictus 1 ekor.

d. Habitat ideal pada Dusun Sucen yang potensial bagi perkembangbiakan nya-muk Anopheles spp yang ditemukan berupa kolam-kolam bekas tambak yang tidak dikelola dengan baik dan persawahan.

e. Sebanyak 3 spesies nyamuk yang Anopheles spp ditemukan pada penang-kapan nyamuk metode resting di sekitar kandang ternak. Dan bersifat suka menggigit binatang (zoofilik).

\section{Saran}

Salah satu upaya dalam mengurangi malaria dengan penggunaan kelambu ketika tidur malam hari sebagai upaya mengurangi kontak dengan nyamuk dalam upaya menekan penularan malaria. Serta mengurangi aktivitas pada malam hari, apabila telah melakukan aktivitas di luar rumah pada malam hari sebaiknya menggunakan obat anti nyamuk. Dan penerapan PHBS (Perilaku Hidup Bersih dan Sehat) lebih ditingkatkan lagi.

Penutupan habitat perkembangbiakan dan pembersihan tumbuhan air yang dapat memudahkan berkembangbiaknya larva dan nyamuk dewasa. Selain itu, memanfaatkan musuh alami (predator larva) dan larvasida sangat membutuhkan informasi mengenai tepat perindukkan sehingga upaya tersebut tepat sasaran.

Peneliti lain diharapkan dapat melakukan penelitian sejenis tetapi hendaknya re-konfirmasi vektor perlu di-lakukan melalui penelitian lanjutan terhadap spesies-spesies Anopheles yang ditemukan untuk memastikan vektor malaria di Desa Cibenda Dusun Sucen Kecamatan Parigi Kabupaten Pangandaran.

\section{DAFTAR PUSTAKA}

Anonim. Atlas Vektor Penyakit di Indonesia. Kementerian Kesehatan; 2011.
Amrul Munif dan Moch.Imron, 2010, Panduan Pengamatan Nyamuk Vektor Malaria cet.pertama, Jakarta: Sagung Seto

Aris Santjaka, 2013, Malaria Pendekatan Model Kausalitas cet. pertama, Yogyakarta; Nuha Medika

Azrul Aswar, 1986, Pengantar Ilmu Kesehatan Lingkungan cet. 4, Jakarta : Mutiara Sumber Widya

Badan Litbangkes. 2008. Laporan Hasil Riskesdas Provinsi Jawa Barat tahun 2007. Jakarta : Badan Litbangkes, Depkes RI.

Badan Litbangkes. Riskesdas 2010. Jakarta : Badan Litbangkes, Kementrian Kesehatan RI, 2010

Depkes RI, Ditjen PPM dan PLP, 1983, Malaria Entomologi 10, Jakarta: Ditjen P3M

Depkes RI, Ditjen PPM dan PLP, 1987, Ekologi Vektor dan Beberapa Aspek Perilaku, Jakarta

Depkes RI, 1993, Malaria Entomoogi 10, Jakarta: Ditjen PPM dan PLP

Depkes RI, 1999, Modul Entomologi Malaria 3, Jakarta: Ditjen PPM dan PLP

Depkes RI,2000, Pemberantasa Penyakit Menular dan Penyehatan,Jakarta: Ditjen PPM dan PLP

Departemen Kesehatan. Dirjen P2PL. Pedoman Vektor Malaria di Indonesia. Jakarta: Departemen Kesehatan. 2006

Depkes RI, Dit.Jen.PP \& PL, 2007, Ekologi dan Aspek Perilaku Vektor, Jakarta: Dit.Jen.PP \&PL

Dhewantara PW, Astuti EP, Pradani FY, 2013. Studi bioekologi nyamuk Anopheles sundaicus di Desa Sukaresik Kecamatan Sidamulih Kabupaten Ciamis . Buletin Peneliti Kesehatan h.41

Ditjen PPM Dan PLP, 2003, Pemberantasan Penyakit Bersumber Binatang, Jakarta: Depkes RI

http://repository.usu.ac.id/bitstream/123456789/2032 5/4/Chapter\%2011.pdf, diakses 1 January 2016, pukul 09.00

Indonesia, Depkes RI, 1993, Epidemiologi Malaria, Jakarta: Depkes RI

Indonesia, Depkes RI, 2009, Pedoman PenatalaksanaanKasus Malaria Di Indonesia, 
Jakarta: Direktorat Jenderal Pengendalian Penyakit dan Penyehatan Lingkungan

, 2007, Vektor Malaria di Indonesia, Jakarta: Ditjen PPM dan PLP

, 2001, Pedoman Ekologi Dan Aspek Perilaku Vektor, Jakarta: Ditjen PPM dan PLP

Iskandar, Adang, dkk, 1985, Pedoman Bidang Studi Pemberantasan Serangga dan Binatang Pengganggu, Jakarta: Proyek Pengembangan Pendidikan Tenaga Sanitasi Pusat

Joshi,G.P.,Self,L.S.,Usman,S.Pant,G.P.,Nelson,M.J and Supalin,1977,Ecologi studies on Anopheles aconitus Donitz in Semarang of Central

Java,WHO/VBC/77,675-682Kusnarti, 2003, "Nyamuk", Diklat Kumpulan Mata

Kuliah Entomologi, Purwokerto; Depkes RI Politeknik Kesehatan Semarang Jurusan Kesehatan Lingkungan Purwokerto

Lukman dkk, 2015, Penentuan Potensi Keberadaan dan Kemunculan Kembali Malaria di Wilayah Pengembangan Pariwisata dan Pemerintah Kabupaten Pangandaran Jawa Barat, Ciamis: Loka Penelitian dan Pengembangan Pemberantasan Penyakit Bersumber Binatang (Loka Litbang P2B2) Ciamis

Mardjan et al. Jenis-jenis Nyamuk yang Ditemukan di Kabupaten Sumbawa, Provinsi Nusa Tenggara Barat. 2002; 5

Munif, A. Panduan pengamatan nyamuk vektor malaria. Jakarta: Sagung Seto, 2010
O’Connor dan Soepanto A. 1979. Kunci Bergambar untuk Anopheles Betina di Indonesia. Jakarta : Ditjen P2M \& PLP, Depkes

Raharjo M, Sutikno SJ, Mardihusodo. Karakteristik Wilayah sebagai Determinan Sebaran Anopheles aconitusdi Kabupaten Jepara. Dalam Firs Congress of Indonesia Mosquito Control Association in the Commemoration of Mosquito Day. Yogyakarta; 2003 : 54-64

Setyaningrum.E.,Aspek Ekologi Tempat Perindukkan Nyamuk Anopheles sundaicus di Pulau Legundi Padang Cermin, Lampung.,Jumal manajemen dan Kualitas Lingkungan Vol 1(3).,1998

Soekimo., M Bang J.H., Sudomo., Pamayun CP, and G.A. Fleming Bionomic of sundaicus and other Anophelines associated with malaria coastal area ofbali (Indonesia).,Sirkuler WHO IVBC/83.885., 1983

Sukowati S. Pendekatan ekosistem dalam pengendalian nyamuk (vektor penyakit). Proceding Seminar Nasional dan Symposium Strategi Pengendalian Nyamuk sebagai Vektor Tular Penyakit dalam Upaya Peningkatan Kualitas Kesehatan Masyarakat. Fakultas Kesehatan Masyarakat Universitas Diponegoro, 2006.h.91-99.

Sushanti, N, et.al, 1999, Fauna Anopheles di Daerah Pantai Bekas Hutan Mangrove Kecamatan Padang Cermin Kabupaten Lampung Selatan,Buletin Penelitian Kesehatan, vol26 no 1, Jakarta: Depkes RI,Badan Penelitian dan Pengem-bangan Kesehatan 